\title{
ПРОГРАМУВАННЯ ПРОЦЕСУ НАВЧАННЯ ЛАЗІННЮ У ВИСІ НА ЗІГНУТИХ РУКАХ УЧНІВ ТРЕТЬОГО КЛАСУ
}

\author{
Худолій О.М., Мірошниченко Д.Т. \\ Харківський національний педагогічний університет імені Г.С. Сковороди
}

\begin{abstract}
Анотація. У статті обгрунтовується програма навчання лазінню у висі на зігнутих руках учнів третього класу. Наводиться план-графік проходження навчального матеріалу. Встановлено, що запропоновані завдання доступні і взаємозв'язані.

Ключові слова: учні, лазіння, навчання, програмування.
\end{abstract}

Постановка проблеми. Лазіння по канату — найбільш складна вправа і без відповідної підготовки учню часто не вдається піднятися навіть на невелику висоту на канаті. Вправи в лазінні по канату потребують доброї силової підготовки і уміння поєднувати рухи руками і ногами.

Досвід роботи учителів фізичної культури свідчить про те, що навчити дітей «цілісним» методом дуже важко. Для навчання учнів фізичним вправам рекомендується спеціально складені програми типу алгоритмічних розпоряджень. Отже розробка програми алгоритмічного типу навчання лазінню по канату для дітей молодшого шкільного віку є актуальною.

Аналіз публікацій. Лазіння по канату розглядається як важливий засіб фізичної підготовки школярів $[4,6,7]$. Навчання лазінню має свої особливості $[7,9]$, найкращий результат дає програмоване навчання. Програмоване навчання в нашій країні стало широко застосовуватися з 1962 року. Під програмованим навчанням розуміється система навчальної роботи з переважно опосередкованим програмним керуванням пізнавальною діяльністю учнів $[1,2]$. Основні відмінні риси програмованого навчання - поділ навчального матеріалу на дрібні порції, підбір завдань на кожну таку порцію і негайний контроль за результатом виконання кожного за-

(c) Худолій О.М., Мірошниченко Д.Т., 2009 вдання (П.Я. Гальперин, [4]). Метод алгоритмічних розпоряджень $є$ найбільш ефективним в процесі навчання фізичним вправам [5, 8, 9, 10]. Ефективність програмованого навчання залежить насамперед від правильного розуміння самого процесу навчання. Оптимізувати процес навчання можна тільки на основі правил переробки інформації. Якщо процес навчання будується в протиріччі з цими правилами, виходячи тільки з уявлення викладача про те, як більш послідовно і «розумно» викласти навчальний матеріал, то метод навчання може виявитися неоптимальним $[3,6,7,10]$.

Зв'язок роботи 3 науковими програмами. Тема дослідження $є$ складовою комплексної програми науково-дослідної роботи кафедри теорії та методики фізичного виховання Харківського національного педагогічного університету імені Г.С. Сковороди з проблеми «Методологія й методика викладання спеціальних дисциплін у педвузі та загальноосвітній школі».

Мета дослідження - розробити програму навчання лазінню у висі на зігнутих руках учнів третього класу.

Методика дослідження. У роботі використані такі методи: аналіз науково-методичної літератури, педагогічні спостереження, педагогічний експеримент, методи математичної статистики. В експерименті реєструвався рівень навченості вправам серій навчальних завдань. Використаний ймовірний підхід 
до оцінки процесу навчання. Для кожної вправи навчальних завданнь розраховувався коефіцієнт навченості: $p=m / n$, де $m$ - кількість успішно виконаних спроб (позначається як «1»-виконано), $n-$ загальна кількість спроб. У подальшому для ймовірностей (p) розраховувалися елементарні статистики; для встановлення взаємозв'язку використовувався кореляційний аналіз, для визначення цілісності запропонованої програми - факторний аналіз. У дослідженнях взяли участь учні третього класу: 16 дівчаток і 14 хлопчиків.

Результати дослідження. Аналіз науково-методичної літератури дозволив встановити алгоритм розробки програми навчання, який складається: 3 формулювання мети навчання, опису вправи, встановлення вимог до учнів, підборунавчальних завдань, визначення точок контролю над засвоєнням вправи, визначення доступних завдань, написання програми, упорядкування тематичного плану графіка.

На основі даних А.М. Шлеміна [10], О.М. Худолія $[6,7]$ була упорядкована програма лазіння у висі на зігнутих руках для школярів молодших класів, яка наведена нижче:

В.п. - вис на зігнутих руках.

1 - зігнути ноги вперед і захопити канат ногами схресно так, щоб зовнішня сторона стопи одної ноги і внутрішня сторона голені другої тісно притискувались до каната.

2 - випрямляючи ноги, ще вище підтягнутись на руках i, зберігаючи захват каната ногами, по черзі перехватити руки вище так, щоб залишитись у висі на зігнутих руках.

Приступати до навчання потрібно з перевірки готовності учнів до оволодіння даною вправою:

1 - перевірити знання про те, що починати лазіння слід з вису на зігнутих руках, а захват каната ногами робити так, щоб стопа і голінь тісно притискувались до каната;

2 - перевірити уміння виконувати вис на зігнутих руках (5-6 сек) на гімнастичній стінці і піднімати зігнуті ноги у висі 5-6 разів.

Якщо ці вимоги виконуються, то можна приступити до навчання лазінню по навчальній програмі приведеній нижче.

Периа серія навчальних завдань.

1.3 вису на зігнутих руках на гімнастичній стінці, повільно розгинаючи руки, перейти у вис за $6-8$ сек. Повторити 6-8 раз.

2. Те саме, але утриматись у висі на зігнутих руках 4-5 сек.

3. 3 вису на гімнастичній стінці підняти зігнуті ноги вперед, як можна вище, і опустити в в.п. Повторити 8-10 раз.

4.3 вису сидячи ноги нарізно на канаті, перейти у вис лежачи 3 почережним перехватом рук у вис стоячи. Повторити 6-8 раз.

Друга серія навчальних завдань.

1. 3 вису стоячи на канаті, відштовхуванням ніг прийняти положення вису на зігнутих руках на канаті і висіти упродовж $4-5$ сек. Повторити $6-8$ раз.
2. Сидячи на гімнастичній лаві захопити ногами гімнастичну палку, імітуючи захват каната. При вірному захваті палка повинна утримуватись вертикально.

3. Сидячи на гімнастичній лаві, захопити канат ногами так, як було описано вище.

4. 3 вису на зігнутих руках захватити канат ногами і утримувати це положення 5-6 сек.

Третя серія навчальних завдань.

1. 3 вису стоячи на зігнутих руках захопити канат ногами i, розгинаючи ноги, перехопити руки вище. Повернутись у в.п.. Повторити 6-8 рази.

2. Те саме, але після випрямлення ніг перехопити руки вище і повернутись в в.п. Повторити 6-8 раз.

Четверта серія навчальних завдань.

1. Те саме, що друга вправа третьої серії, але після перехвату рук, згинаючи ноги, захопити ними канат вище і повернутись у в.п. Повторити $6-8$ раз.

2. Те саме, але виконати $2-3$ перехвати руками i ногами і повернутись в в.п.

3 . Те саме, але виконати 4-5 перехватів.

4. Лазіння по канату на 2 м і повернення.

5. Лазіння по канату на задану відстань: хлопчики -3 м, дівчатка -2 м.

Суттю данного дослідження є обгрунтування вищенаведеної навчальної програми. Результати проаналізовані за допомогою елементарних статистик, кореляційного і факторного аналізу.

Результати аналізу наведені в таблиці 1, 2, 3, 4, 5 .

Кореляційний аналіз показав, що між рівнем навченості навчальним завданням і умінням лазити по канату у висі на зігнутих руках спостерігається висока кореляційна залежність $(0,771-0,980)$. Кожне завдання позитивно зв'язане з наступним, це свідчить про те, що вони підібрані по складності. Крім цього виявлена висока кореляційна залежність, як між завданнями серії, так і між серіями навчальних завдань. Звертає увагу те, що між навченістю вправам техніки руху руками і ногами існує позитивна залежність $(0,463-0,520)$.

Отже, в запропонованій програмі всі навчальні завдання позитивно зв'язані з цільовою руховою навичкою. Між завданнями різних серій існує позитивний кореляційний зв'язок (таблиця 1).

У результаті факторного аналізу виділилося три фактори. Аналіз показав, що перший фактор має найбільшу вагу і $є$ домінантним. Иого можна характеризувати як «цілісність навчальної програми», тому що найбільшу кореляційну залежність з ним мають «Лазіння на задану відстань» $(0,902 ; 0,895)$, а інші показники ввійшли в фактор з досить високими коефіцієнтами кореляції (таблиця 2).

Отже, пропонована програма характеризується цілісністю. Окремі групи вправ не виділяються як структурні елементи, це вказує на високу залежність кожної вправи від попередньої.

У таблиці 3 наведені результати навчання руховим завданням. Аналіз показав, що для засвоєння 


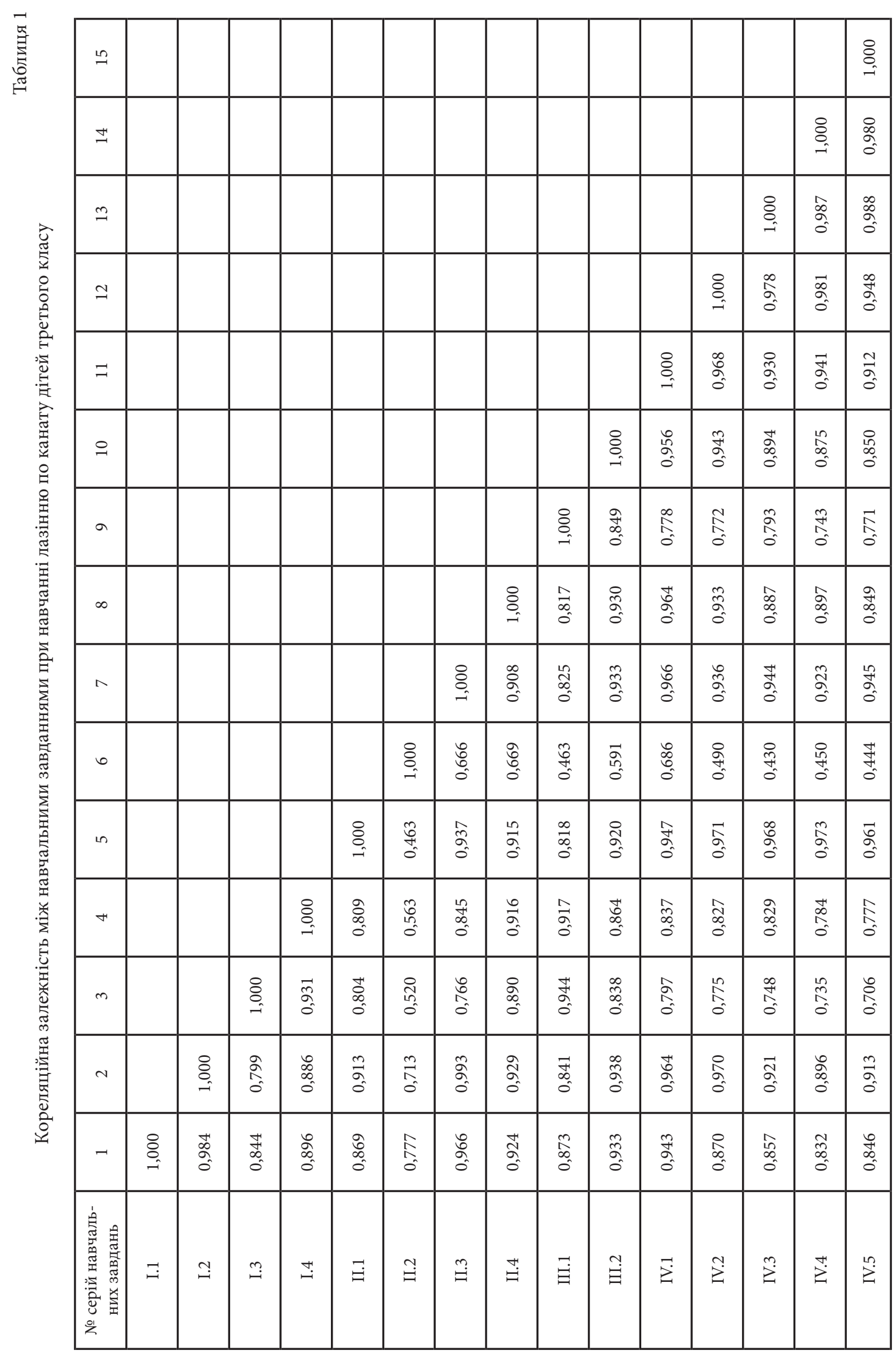


Таблиця 2

Структура рухових завдань в програмі навчання лазінню по канату учнів третього класу

\begin{tabular}{|l|c|c|c|c|}
\hline \multirow{2}{*}{$\begin{array}{c}\text { № } \\
\text { 3/п }\end{array}$} & \multicolumn{3}{|c|}{ Фактори } & \multirow{2}{*}{$\mathrm{h}^{2}$} \\
\cline { 2 - 4 } & 1 & 2 & 3 & \\
\hline I.1 & 0,582 & 0,556 & 0,581 & 0,985 \\
\hline I.2 & 0,701 & 0,478 & 0,510 & 0,980 \\
\hline I.3 & 0,394 & 0,865 & & 0,970 \\
\hline I.4 & 0,481 & 0,781 & 0,323 & 0,945 \\
\hline II.1 & 0,846 & 0,462 & & 0,974 \\
\hline II.2 & & & 0,953 & 0,991 \\
\hline II.3 & 0,765 & 0,424 & 0,459 & 0,976 \\
\hline II.4 & 0,649 & 0,572 & 0,441 & 0,943 \\
\hline III.1 & 0,454 & 0,841 & & 0,955 \\
\hline III.2 & 0,688 & 0,562 & 0,382 & 0,923 \\
\hline IV.1 & 0,766 & 0,415 & 0,477 & 0,986 \\
\hline IV.2 & 0,860 & 0,419 & & 0,980 \\
\hline IV.3 & 0,884 & 0,418 & & 0,991 \\
\hline IV.4 & 0,902 & 0,360 & & 0,984 \\
\hline IV.5 & 0,895 & 0,356 & & 0,969 \\
\hline & 7,373 & 4,453 & 2,725 & 14,551 \\
\hline \% & 50,670 & 30,603 & 18,728 & 100 \\
\hline
\end{tabular}

Таблиця 3

Результати навчання серіям навчальних завдань, кількість повторень вправи до $\mathrm{p}=0.8$

\begin{tabular}{|c|c|c|}
\hline № 3/п & $\mathrm{X}$ & $\mathrm{s}$ \\
\hline I.1 & 28 & 8,726 \\
\hline I.2 & 24,250 & 7,504 \\
\hline I.3 & 32,000 & 11,950 \\
\hline I.4 & 29,500 & 9,086 \\
\hline II.1 & 26,750 & 6,152 \\
\hline II.2 & 32,250 & 9,594 \\
\hline II.3 & 30,500 & 8,349 \\
\hline II.4 & 25,000 & 27,775 \\
\hline III.1 & 30,000 & 22,039 \\
\hline III.2 & 30,000 & 32,071 \\
\hline IV.1 & 32,250 & 27,484 \\
\hline IV.2 & 18,250 & 5,773 \\
\hline IV.3 & 18,750 & 6,861 \\
\hline IV.4 & 18,250 & 5,741 \\
\hline IV.5 & 20,750 & 5,541 \\
\hline
\end{tabular}

рухових завдань достатньо кожне повторювати 6-10 разів в одному занятті. Для навчання лазанню по кана-
Таблиця 4

План-графік навчання лазінню по канату дітей 3-го класу

\begin{tabular}{|l|l|l|l|l|l|l|l|l|l|l|l|l|l|l|}
\hline & 1 & 2 & 3 & 4 & 5 & 6 & 7 & 8 & 9 & 10 & 11 & 12 & 13 & 14 \\
\hline I.1 & + & + & + & + & & & & & & & & & & \\
\hline I.2 & + & + & + & + & & & & & & & & & & \\
\hline I.3 & + & + & + & + & & & & & & & & & & \\
\hline I.4 & + & + & + & + & & & & & & & & & & \\
\hline II.1 & + & + & + & + & & & & & & & & & & \\
\hline II.2 & + & + & + & + & & & & & & & & & & \\
\hline II.3 & + & + & + & + & & & & & & & & & & \\
\hline II.4 & & + & + & + & & & & & & & & & & \\
\hline III.1 & & & & & + & + & + & & & & & & & \\
\hline III.2 & & & & & & + & + & + & & & & & & \\
\hline IV.1 & & & & & & & & + & + & + & & & & \\
\hline IV.2 & & & & & & & & & & + & + & & & \\
\hline IV.3 & & & & & & & & & & & + & + & & \\
\hline IV.4 & & & & & & & & & & & & + & + & + \\
\hline IV.5 & & & & & & & & & & & & + & + & + \\
\hline
\end{tabular}

ту пропонуємо план-графік і програму, які пройшли експериментальну перевірку (таблиця 4, 5).

\section{Висновки}

1. У запропонованій програмі навчання лазінню по канату всі навчальні завдання позитивно зв’язані з цільовою руховою навичкою. Між завданнями різних серій існує позитивний кореляційний зв'язок (таблиця 1).

2. Навчальна програма характеризується цілісністю. Окремі групи вправ не виділяються як структурні елементи, це вказує на високу залежність кожної вправи від попередньої.

3. Встановлено, що навчальні завдання доступні для школярів третіх класів. Послідовне навчання кожній групі вправ до рівня навченності 75-80 \% сприяє ефективному засвоєнню рухового матеріалу.

Перспективним напрямком подальших розвідок $€$ встановлення закономірностей процесу навчання руховим діям дітей молодшого шкільного віку.

\section{Список літератури}

1. Берг А.И., Тихонов И.И. Проблемы программированного обучения // Программированное обучение. - Л.: Знание, 1968. - С. 3-22.

2. Беспалько В.П. Программированное обучение: дидактические основы. - М.: Высшая школа, 1970. $-300 \mathrm{c}$. 
Таблиця 5

Програма навчання лазінню по канату дітей 3-го класу

\begin{tabular}{|c|c|c|c|}
\hline $\begin{array}{l}\text { № } \\
3 / \Pi\end{array}$ & Інформаційний кадр & Операційний кадр & Контрольний кадр \\
\hline I.1 & $\begin{array}{l}3 \text { вису на зігнутих руках на гімнастичній стінці, по- } \\
\text { вільно розгинаючи руки, перейти у вис за } 6-8 \text { сек }\end{array}$ & $\begin{array}{l}\text { Вправу виконувати в одному } \\
\text { темпі. Повторити 6-8 раз }\end{array}$ & \\
\hline I. 2 & $\begin{array}{l}\text { Те саме, але утриматись у висі на зігнутих руках } 4-5 \\
\text { сек }\end{array}$ & $\begin{array}{l}\text { Вправу виконувати в одному } \\
\text { темпі. Повторити 6-8 раз }\end{array}$ & Утримувати вис 5 сек \\
\hline I.3 & $\begin{array}{l}3 \text { вису на гімнастичній стінці підняти зігнуті ноги } \\
\text { вперед, як можна вище, і опустити у в.п. }\end{array}$ & $\begin{array}{l}\text { Вправу виконувати в одному } \\
\text { темпі. Повторити } 2-3 \text { раз }\end{array}$ & \\
\hline I.4 & $\begin{array}{l}3 \text { вису сидячи ноги нарізно на канаті, перейти у вис } \\
\text { лежачи з поперемінним перехватом рук у вис стоячи }\end{array}$ & $\begin{array}{l}\text { Зберігати суглобні кути. Повто- } \\
\text { рити 6-8 раз }\end{array}$ & Уміти перейти в вис лежачи \\
\hline II.1 & $\begin{array}{l}3 \text { вису стоячи на канаті, відштовхуванням ніг при- } \\
\text { йняти положення вису на зігнутих руках на канаті і } \\
\text { висіти на протязі } 4-5 \text { сек }\end{array}$ & $\begin{array}{l}\text { 3берігати суглобні кути. Повто- } \\
\text { рити 6-8 раз }\end{array}$ & Утримувати вис 5 сек \\
\hline II. 2 & $\begin{array}{l}\text { Сидячи на гімнастичній лаві захопити ногами гім- } \\
\text { настичну палку, імітуючи захват каната }\end{array}$ & $\begin{array}{l}\text { Слідкувати за виконанням за- } \\
\text { хвату ніг }\end{array}$ & \\
\hline II. 3 & $\begin{array}{l}\text { Сидячи на гімнастичній лаві, захопити канат ногами } \\
\text { так, як було описано вище }\end{array}$ & $\begin{array}{l}\text { Слідкувати за виконанням за- } \\
\text { хвату ніг }\end{array}$ & \\
\hline II.4 & $\begin{array}{l}3 \text { вису на зігнутих руках захватити канат ногами i } \\
\text { утримувати це положення 5-6 сек }\end{array}$ & $\begin{array}{l}\text { Зберігати суглобні кути. Повто- } \\
\text { рити 6-8 раз }\end{array}$ & Утримувати вис 5 сек \\
\hline III.1 & $\begin{array}{l}3 \text { вису стоячи на зігнутих руках захопити канат но- } \\
\text { гами i, розгинаючи ноги, перехопити руки вище }\end{array}$ & $\begin{array}{l}\text { Слідкувати за роботою ніг та } \\
\text { рук }\end{array}$ & Рівень навченості 80\% \\
\hline III. 2 & $\begin{array}{l}\text { Те саме, але після випрямлення ніг перехопити руки } \\
\text { вище і повернутись у в.п. }\end{array}$ & $\begin{array}{l}\text { Слідкувати за роботою ніг та } \\
\text { рук }\end{array}$ & Рівень навченості 80\% \\
\hline IV.1 & $\begin{array}{l}\text { Те саме, що друга вправа третьої серії, але після пе- } \\
\text { рехвату рук, згинаючи ноги, захопити ними канат } \\
\text { вище і повернутись у в.п. }\end{array}$ & $\begin{array}{l}\text { Слідкувати за роботою ніг та } \\
\text { рук }\end{array}$ & Рівень навченості 80\% \\
\hline IV.2 2 & $\begin{array}{l}\text { Те саме, але виконати } 2-3 \text { перехвати руками і нога- } \\
\text { ми і повернутись у в.п. }\end{array}$ & $\begin{array}{l}\text { Слідкувати за роботою ніг та } \\
\text { рук }\end{array}$ & Рівень навченості 80\% \\
\hline IV.3 & Те саме, але виконати 4-5 перехватів & $\begin{array}{l}\text { Слідкувати за роботою ніг та } \\
\text { рук }\end{array}$ & Рівень навченості 80\% \\
\hline IV.4 & Лазіння по канату на 2 м і повернення у в.п. & $\begin{array}{l}\text { Слідкувати за роботою ніг та } \\
\text { рук }\end{array}$ & Пролізти 2 м \\
\hline IV.5 & $\begin{array}{l}\text { Лазіння по канату на задану відстань: хлопчики - } \\
3 \text { м, дівчатка }-2 \text { м }\end{array}$ & $\begin{array}{l}\text { Слідкувати за роботою ніг та } \\
\text { рук }\end{array}$ & Виконати завдання \\
\hline
\end{tabular}

3. Гальперин П.Я. К теории программированного обучения. - М.: Знание, 1967. - 44 с.

4. Гогін O.В., Гогіна T.I. Розвиток силових здібностей на уроках легкої атлетики в школі // Теорія та методика фізичного виховання. - Харків: ОВС, 2009. - № 4. - C. $24-34$.

5. Мірошниченко Д.Т. Методика навчання акробатичним вправам учнів молодших класів // Теорія та методика фізичного виховання. - Харків: ОВС, 2007. — № 12. - С. 29-31.

6. Худолій О. М. Позакласні заняття гімнастикою в школі. // Теорія та методика фізичного виховання. — Харків: ОВС, 2007. — № 2. - С. 19-32.
7. Худолій О.М. Прикладні гімнастичні вправи в школі // Теорія та методика фізичного виховання. - Харків: ОВС, 2008. — № 11. - С. 19-26.

8. Худолій О.М. Програмоване навчання руховим діям // Педагогіка та психологія. 36. наукових праць. Харків: ХГПУ, 2000. - Вип. 15. - С. 165-167.

9. Черняев В.В. Обучающие программы //Физическая культура в школе. - 1982. - № 9. - С. 32-34.

10. Шлемин А.М. Один из эффективных методов // Физкультура в школе. — 1981. - № 11. - С 26-29.

Надійшла до редакиії 02.02.2009

Худолей О.Н., Мирошниченко Д.Т. Программирование процесса обучения лазанью в висе на согнутых руках учеников третьего класса.

В статье обосновывается программа обучения лазанью в висе на согнутых руках учеников третьего класса. Приводится план-график прохождения учебного материала. Установлено, что предложенные задания доступны и взаимосвязаны.

Ключевые слова: ученики, лазанье, обучение, программирование.

Khudolii O.N., Miroshnichenko D.T. Programing of process of teaching to climb in to hang on the arcuated hands of students of the third class.

In article the program is grounded of teachingto climb in to hang on the arcuated hands of students of the third class. A plan-the graph is led of passing of educational material. It is set, that the offered tasks are accessible.

Keywords: students, to climb, teaching, programing. 